\title{
Urban youth preserving the environmental commons: student learning in place-based stewardship education as citizen scientists
}

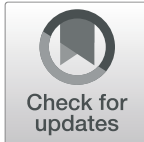

Erin Gallay ${ }^{1 *}$ (D) Alisa Pykett ${ }^{1}$, Morgan Smallwood ${ }^{2}$ and Constance Flanagan ${ }^{2}$

\begin{abstract}
Background: The urban ecology and especially youth of color living in urban spaces have received relatively little attention in environmental education. The purpose of this work was to assess what urban youth learn about the Environmental Commons by participating in place-based stewardship education (PBSE) projects. By the Environmental Commons we refer to: 1) the natural resources and systems on which all life depends, and 2) the public spaces and processes in which people work together to determine how they will care for those resources and for the communities they inhabit. Core principles in all projects include: experiential education about the natural environment in the local urban ecology; students' scientific and civic agency; and collective learning/action in teams of students, teachers, and adult community partners committed to sustaining the local ecosystem. After engaging in the projects, students were asked to reflect in their own words on what they had learned.

Results: The reflective essays of 205 children (14\% in 4th-5th grade) and adolescents ( $86 \%$ in 6 th-12th grade) from predominantly (79\%) racial/ethnic minority backgrounds and residing in urban communities were analyzed. Coding was informed by Environmental Commons theory and by Elinor Ostrom's work on the practices of groups that are effective in stewarding common pool resources, with the highest number of coding categories assigned to any individual response being 8 . Analyses revealed that students: became aware of human impact on nature and were resolved to redress negative impact; identified as stakeholders of the environmental commons and their local community; felt a sense of pride and collective efficacy in their team efforts that benefitted both the human and more than human communities with whom they identified. Verbatim excerpts from students' reflective essays are included to illustrate the range of ways that youth interpret in their own words the interdependence of human life with other living systems and the responsibility of humans to work together to sustain those living systems.

Conclusions: Since younger generations will bear the burdens of the climate crisis, it is imperative that they reimagine what gives their lives meaning. The PBSE model documented here offers hope for nurturing an identification and commitment to the Environmental Commons in urban youth.
\end{abstract}

Keywords: Environmental commons, Citizen-science, Community science, Urban environmental education, Collective environmental action, Place-based education, Ecological citizenship, Civic ecology

\footnotetext{
*Correspondence: egallay@wisc.edu

'School of Human Ecology, University of Wisconsin-Madison, 1300 Linden Dr,

Madison, WI 53706, USA

Full list of author information is available at the end of the article
}

(c) The Author(s). 2020 Open Access This article is licensed under a Creative Commons Attribution 4.0 International License, which permits use, sharing, adaptation, distribution and reproduction in any medium or format, as long as you give appropriate credit to the original author(s) and the source, provide a link to the Creative Commons licence, and indicate if changes were made. The images or other third party material in this article are included in the article's Creative Commons licence, unless indicated otherwise in a credit line to the material. If material is not included in the article's Creative Commons licence and your intended use is not permitted by statutory regulation or exceeds the permitted use, you will need to obtain permission directly from the copyright holder. To view a copy of this licence, visit http://creativecommons.org/licenses/by/4.0/. 
Restraint in resource use and living within nature's limits are preconditions for social justice. The commons are where justice and sustainability converge, where ecology and equity meet. .... The breakdown of a community, with the associated erosion of concepts of joint ownership and responsibility, can trigger the degradation of common resources. -Vandana Shiva ([1], p. 50).

\section{Background}

The realities of environmental degradation, and the climate emergency in particular, demand a fundamental reimagining of the things that give human lives meaning. Even the most optimistic scenarios based on lowering carbon emissions, portend a need for major changes in lifestyles, values, and orientations of personal aspirations with those of a broader community [2]. As younger generations will shoulder disproportionate burdens associated with the climate crisis [3], it is critical to develop their awareness of the fundamental ways that the wellbeing of humans and other living species are intertwined. Developing the younger generation's environmental awareness, commitments and understanding of environmental issues as collective action problems in which they and fellow citizens are stakeholders, will be critical in this future.

Youth is a time in life when identities and aspirations are still forming [4]. Thus, learning about the interdependence of human life with the natural environment in these years is likely to have a lifelong impact. Emphasizing such interdependence within the urban context is especially important because the urban ecology has not been at the forefront of environmental education and because demographic trends indicate that urban areas are where people increasingly are living [5].

Vandana Shiva's [1] insights about the importance of an identification with a community and a responsibility for sustaining that community are at the core of the Environmental Commons project discussed in this paper. Concepts such as the commons, interdependence, and collective action, are central to civic and environmental understanding [6], yet there is limited research on how students express these concepts and, more particularly, whether engaging in environmental action affects their civic and environmental stewardship understanding and dispositions [7]. In this project, we examine a model of place-based stewardship education (PBSE) in which young people address local environmental issues, and evaluate what students learn about the environmental commons. Specifically, we assess 4 th-12th grade students' civic learning, commitments and skills, identification with their communities, and their commitments to and learnings about the environmental commons, through participation in PBSE in urban communities.

\section{Environmental commons theory}

We define the environmental commons as: 1) the natural resources and systems on which all life depends, and 2) the public spaces and processes in which people work together to determine how they will care for those resources and for the communities they inhabit $[8,9]$. Our theory about the environmental commons has been informed by the work of political economist and Nobel prize winner Elinor Ostrom, who challenged the inevitability of a so-called tragedy of the commons [10] the idea that people, driven by self-interest, will use up and destroy the resources on which their communities depend.

In contrast to the idea of the tragedy of the commons, Ostrom and her colleagues studied groups who were successful in managing and sustaining what they referred to as common pool resources (CPRs) that provide benefits to everyone but can be depleted if overused [11]. Characteristics of effective groups include: proximity to the CPR; the strength of members' identification with the team and its goal of sustaining the resource; and dynamics within the group including mutual respect, responsibility and communication over time that enable members to know one another and to build trust [11, 12]. In documenting these PBSE projects, we aim to advance environmental commons theory and draw from Ostrom's work $[11,12]$ to highlight educational practices in PBSE that parallel the elements of effective groups and thus should nurture students' commitments to and capacities to sustain the environmental commons.

\section{Environmental justice and interdependence in the urban ecology}

The projects discussed in this paper take place in the highly industrialized Southeastern Michigan metropolitan area, and so explore how the natural environment and human interdependence with it is experienced in the urban ecology. The majority of these projects take place in urban low-income communities of color where issues of environmental and climate justice are salient. Not only is there an inverse relationship between community income levels and environmental pollution [13] but within the United States and globally, those populations who have contributed the least in greenhouse gases will likely experience the worst impacts of climate change [14].

Yet, with the exception of environmental justice and eco-justice education, they have not been at the center either of environmental education or of the environmental movement $[15,16]$. Furthermore, in popular and consumer culture, representations of humans in nature 
typically convey images of young, largely white people exploring pristine natural spaces. Such depictions ignore the connections of people of color with the land and thus limit the groups we imagine might care about nature [17].

In contrast to a view of nature as a pristine landscape apart from the city, projects discussed here adopt the 'civic ecology' framework of urban environmental work, emphasizing the city as a social-ecological system, and human impact and agency $[18,19]$. Research on youth environmental activism indicates that young people of color are more likely to get involved when they see connections between the health of the environment and that of their community and culture $[20,21]$.

\section{Student projects as part of the Southeast Michigan stewardship coalition (SEMIS)}

The projects discussed in this paper are part of the PBSE model of the Southeast Michigan Stewardship Coalition (SEMIS). The environmental issues on which students work differ from one community to another; however, all projects reflect a core set of principles and practices. First, consistent with the philosophy of place-based education [22-24], they emphasize the value of local place, i.e., the community beyond the walls of the school as a source for learning and as a community to which students can contribute. All projects involve experiential education about the natural environment in the local community and are responsive to local conditions. Thus, we have referred to them as examples of place-based stewardship education [20]. Second, all projects emphasize students' scientific and civic agency: they are inquirybased; incorporate students' observations, questions, insights, and voice; and engage students in data collection, analyses, and actions to mitigate an environmental problem in their community. Third, based on the principle that environmental issues are collective action problems that require multiple perspectives and teamwork to solve, students work in groups with fellow students, teachers, and adults from the local community who are committed to sustaining the local ecosystem. Not only are projects structured as collaborative, but a final element includes student teams presenting their projects in public venues (in community forums with students and teachers from other schools, with city or county officials, and members of the public).

\section{What might students learn through their participation in PBSE?}

We expect that PBSE's focus on what students can learn about and contribute to their local community should engender the joint ownership and feelings of responsibility for the community to which Shiva [1] alludes. Youths' pro-environmental actions also should increase awareness of human interdependence with and impact on the natural environment in the urban landscape. As human interdependence with nature is an integral part of 'place' in many communities, PBSE that engages students in actions to monitor human impact and restore the local ecology [25] should nurture ethical awareness in students rooted in an understanding of interdependence and community.

\section{Methods}

In this paper, we summarize the reflective essays of 205 4-12th grade students from ethnic minority and low-income urban communities in the United States who worked in teams to mitigate environmental problems in their communities. During the 2015-2016 school year, we collected short reflective essays from students participating in SEMIS projects. The prompt for these essays was in the form of a letter to the SEMIS Coalition: Write a letter to the SEMIS Coalition telling them why you think the work you did in (project specific) was important. What did you learn about your community, other people or species in your community or the environment from the work you did? What did you learn about what kids can do to solve environmental problems in their communities? How has your community or the environment changed because of your work? Teachers and students were informed that the purpose of the essays was not to evaluate student knowledge or to give thanks to SEMIS, but to have students reflect on their experience in their own words.

\section{Sample}

Data were collected from 205 4-12th graders (78\% of whom were 9th-12 graders, ages approximately 14-18 years) from three communities, two of which served students from low-income families. In the United States, students are eligible for a free or reduced-cost lunch at school if their family's income falls below a particular threshold. In two of the communities, $75 \%$ of students were eligible and in the third, $21 \%$. The sample $(51 \%$ male) was predominantly students of color, $79 \%$ identifying as African-American, Latinx, or multiracial.

\section{Content of students' environmental projects: what did students do?}

As shown in Table 1, the content of some student projects discussed in this paper focused closely on conservation, protection and remediation of environmental issues, such as: invasive species removal, implementing permaculture practices, and water quality investigations. The majority of projects stressed the connection of the 
Table 1 Student Project Content

\section{Description of student projects}

A study of the ecological history of land use in the community and humans' relationships to their food which led to permaculture practices in growing food on the school grounds.

An investigation of a local urban park's ecological and social history, water quality sampling and storm water management leading to flood mitigation through installation of a bioswale.

Community mapping and investigations which led to studies of local food economies and urban gardens.

Water quality and habitat health investigations of local water bodies which led to design and creation of water filtration systems.

Studies of sustainability, biodiversity, local agriculture and food systems, incorporating climate change research, invasive species removal, construction and maintenance of school food gardens and harvesting vegetables.

Community surveys, planning, design and creation of a community park by reclaiming neighborhood abandoned houses and vacant lots.

Photo-essays of strengths and opportunities in the community's natural and built environments and community murals of local African American history.

A study of availability and access to healthy, pesticide free food which led to planting and care of an urban community garden.

built environment with environmental and human health and safety, such as: reclaiming abandoned areas as public park spaces; green infrastructure solutions to reduce stormwater runoff; ecosystem services and tree plantings on campus; food injustice and sustainable farming practices through community gardens; and investigating strengths and opportunities in the natural and built environments.

\section{Analyses}

Prior to coding students' essays, three coders each read a set of the sample for emergent themes. In addition, the coding process was informed by research on environmental identity [26, 27], on common-pool resources [12], and on our observations of how the students in these projects experienced the natural environment within their urban context. A total of 14 categories captured all of the students' responses, although only 11 are relevant to the topic of this paper ${ }^{1}$.

\section{Results}

Each reflective essay could be assigned an indefinite number of codes, with a maximum of 8 codes being assigned to any one response, thus, individual students' reflections are counted in more than one coding category. For the sample of 205 students, an average of 4.6

\footnotetext{
${ }^{1}$ The three categories that are not included in this paper were: scientific/environmental knowledge; helping that was not connected either to the environment or the community; and a general other category
}

categories were assigned to responses. Percentages below, and as shown in Table 2, indicate how frequently a particular coding category was referenced in the 205 reflective essays.

Although the reflective essay prompt did not ask students who benefitted from their work, many mentioned the impact they felt their projects had on the community or commons. In order to tease apart whether this was primarily a reference to the human community or included other species (more than human), we used two categories based on whether their response emphasized people and/or the environment/nature as the beneficiary of their efforts.

\section{Human Commons}

Fifty-seven percent of the responses referenced the human community (coding category 1): “... we could help a lot of people with bad water around the world" with many alluding specifically to how the impact of their work on the natural environment within the urban landscape affected people: "There are no more [lakes] of water in front of peoples [sic] houses no more. So what we did for the community really worked." Responses coded in this category also focused on specific benefits to humans from protecting nature, such as; a means of improving safety: "[we] shared our ideas of making this neighborhood a safe place to live"; for the benefit of human health: "it is important to cultivate the natural land we have with gardens, farming space, greenhouses, etc. to provide efficient and healthier meals to our communities"; and as a natural resource for people: "bees make honey for people." While references to a human community or commons as coded here do not necessarily reflect an anthropocentric view in the sense that the student sees humans as more important and valued than others [28], this category does suggest that students' awareness of the natural environment is processed through the lens of its benefits to humans.

\section{Environmental Commons}

That said, $42 \%$ of the responses referenced other species or natural systems as part of the community or commons (coding category 2): "we have a lot of plants that play a big part in the communities" and "my community has two water systems, one from Red River and the other from Green River." Some alluded to the urban coexistence of humans and other animals and the more than human community as the beneficiaries of their work: "[my city] is full of animals and like [my city's] population is just the same amount of animals in the area and that is why I try to help this community." Still others referenced the responsibility that people should shoulder for nature: "we should keep up our 
Table 2 Coding Categories and Descriptions

\begin{tabular}{|c|c|c|}
\hline Code title & Description & $\begin{array}{l}\% \text { of } \\
\text { Students }\end{array}$ \\
\hline $\begin{array}{l}\text { 1. Human Community/ } \\
\text { Commons }\end{array}$ & $\begin{array}{l}\text { Response referenced humans as the community/commons or a more anthropocentric view } \\
\text { emphasizing human need, impact, or beneficiaries of the work. }\end{array}$ & $57.07 \%$ \\
\hline 2. Environmental Commons & $\begin{array}{l}\text { Response referenced other species or natural systems as part of the community or commons and/or } \\
\text { emphasized the environment (plants, animals, etc.) as primary beneficiaries, a more biocentric view. }\end{array}$ & $41.46 \%$ \\
\hline $\begin{array}{l}\text { 3. Membership/pride/ } \\
\text { connection }\end{array}$ & $\begin{array}{l}\text { Response indicated solidarity or a personal relationship with, or expressed pride or membership in a } \\
\text { group, community or place. }\end{array}$ & $34.63 \%$ \\
\hline 4. Collective Nature/Need/Ability & $\begin{array}{l}\text { Response references the collective nature of the work and need for collective action to address } \\
\text { environmental issues. }\end{array}$ & $34.15 \%$ \\
\hline 5. Positive Human Impact & Response references positive human impact on the environment or community. & $76.1 \%$ \\
\hline 6. Negative Human Impact & Response references negative human impact on the environment or community. & $32.20 \%$ \\
\hline $\begin{array}{l}\text { 7. Environmental identity/ } \\
\text { sensitivity }\end{array}$ & Response expressed connection with, care or concern for the natural world. & $15.12 \%$ \\
\hline $\begin{array}{l}\text { 8. Interdependence/limits of } \\
\text { ecological systems }\end{array}$ & Response referenced ecological interdependence and the limits of natural systems. & $20.49 \%$ \\
\hline 9. Generativity/Leadership & Response referenced being an example to others and sharing ideas, leaving a positive legacy. & $25.37 \%$ \\
\hline 10. Efficacy/Empowerment & $\begin{array}{l}\text { Response referenced the belief in one's ability to impact change in the environment/community or } \\
\text { feelings of confidence and power taking action. }\end{array}$ & $51.22 \%$ \\
\hline 11. Civic Skills & $\begin{array}{l}\text { Response referenced developing civic skills/dynamics that make work successful, such as public } \\
\text { speaking, group work, communication, etc. }\end{array}$ & $11.71 \%$ \\
\hline
\end{tabular}

environment because it cant do it on it [sic] own." Including the more than human world as part of a community identity reflects Wilson's [29] idea of biophilia, i.e., that people have an innate urge to affiliate with other forms of life.

Some responses clearly separated community from the environment: "I think the project is important because it's helping not only the community but also the environment." Others included both the human and more than human communities, showing how a biocentric viewpoint can extend inherent value to all living things: "We know we should not cut trees down because they suplie [sic] us with fresh oxygen and they are home to many species of animals. With our learning garden it has become a home for many species of animals such as worms, bees, and spiders."

\section{Membership/Connection/Identification}

Membership in a community or commons has an aspect of caretaking to it, and we were interested in students' identification with a community, i.e., their sense of attachment to or identification with a local place or group. Therefore, we coded (coding category 3) for references that indicated a sense of solidarity or relationship with their place or community ( $m y$ community, our Great Lakes). Distinguished from general references to the human or more-than human commons, $35 \%$ of the responses alluded to a sense of connection, attachment to or pride in being part of a school, city or natural community, gained through their projects. While some projects lent themselves to developing a collective identity with the larger community and others with classroom peers or with the school, themes of unity through working together infused both.

In this category, the "group" with whom the students identified, included place in the sense of an ecological community: "It also shows that we are good people to our river" as well as references to identification with their city: "[City name] will grow back again and that's important because I've lived here most of my life and it's part of me." This communal identity and sense of solidarity often came about when students' perceptions of their communities changed and when they themselves changed the community by being an active part of it:

I've learned that teens like ourselves could make a change and stop the pollution in the rivers and remake it healthy for our community and wildlife again. Our community has changed because of the observations and research we didn't know how bad we were turning our community until we seen it for ourselves and that changed our outlook on life itself.

\section{Collective nature/need}

All projects were implemented as collective or team projects, which is likely why many students (34\%) referenced the need for and benefits of team or group efforts (coding category 4). Some students referenced the coming together of people as one of the benefits of the project: "I've learned that they're our [sic] actually many things we can do to fix our community and help bring 
us together more than we think in ways our gardening experience has brought our class together because we were all so excited about actually gardening. This lesson has just opened my eyes to looking into things that can help bring my community together."

Many students wrote about learning that working together can solve problems, in contrast to working alone, with one noting "If people work together you can get alot [sic] done and make things better than working alone." Students referenced this collective ability, commenting on the effectiveness of working together and the power of group efforts.

Some focused specifically on the act of coming together for a common or shared goal of community improvement: "I think it's important to bond with your community as well as doing good things with them as well. Coming together was the first part, planting a fresh garden was the next step. Doing something as a community \& bring [sic] people together giving people a chance to bond...".

In some cases students projected from the process their group went through (seeing a problem and taking action) to people in general: "I learned that when there is a crisis in a community people come together to fix the issue." Still others referenced the imperative of collective action in light of the scale of environmental work, as showcased by the student who stated "I think this project was important because we need to know now before its to [sic] late one of us could grow up and change the world because they were inspired by this project."

\section{Positive Human Impact}

If youth are going to choose behaviors to ensure a sustainable Earth, it is imperative that they realize the impacts of humans (both positive and negative) on the Earth. Positive human impact (coding category 5) was the category referenced most often, with $76 \%$ of students including this in their responses. Undoubtedly, this reflects the proactive nature of these projects, the sense of agency students feel from their actions, and even the community-based nature of the work. Responses in this category included specific references to helping the community or the natural environment: "I also learned that kids do have an impact to make our community a better place to live in..." and that people care: "I learned that some people and our community care about our Earth, and how it is treated."

Learning about human impact on the environment motivated some to reevaluate the lifestyles and consumption patterns to which they were accustomed. One student contrasts the effects of growing local food with the costs to the environment of the current industrial system of food production and explains how their work additionally addressed issues of social justice, i.e., sharing locally grown food with marginalized groups who have little access to fresh food:

We students can help the environment by eating the food we grow ourselves and eliminate emissions that are being produced by food transportation across countries. This garden didn't only benefit us but whole [City]. The food we grow is being given out to churches and homeless shelters to provide them with fresh nutritious produce.

\section{Negative human impact}

An important aspect of developing a commitment to the commons is realizing both the good people can do and the damage that humans can wreak on the world, with $32 \%$ of the reflective essays coded for some reference to negative human impact (coding category 6). This is showcased by the student who noted about their school garden project, "the environmental changes caused by my community was that we made a garden but the bad things we did were not many people walk to school so a lot of cars cause pollution." As this student points out, positive and negative human impact are not always mutually exclusive. Statements coded in this category were on a continuum of more general negative impact: "I learned that people are gross and it [sic] killing living things in our environment" to the more specific: "I learned that the enviorment [sic] gets treated bad and gets trashed so we need to recycle, and stop littering." Of those students who wrote about detailed negative human impact, there were some who showed a more sophisticated understanding, such as one who noted "Most of the time our food travels more than we do and to do so it takes pesticides and hormones to get the job done. Just like "bulk" food items that are huge (e.g., large bananas) those are injected with hormones."

The majority of responses coded for negative human impact referenced either actions, inactions, apathy, or silence. Often there was a pessimistic view of people coloring these remarks such as the student who wrote: "I learn that some people just don't care about where they live and how they live in our community. Students can work together and do anything to change our community but they chose not to." Occasionally, students' focus on the negative impact of humans on their community's environment led to their own sense of apathy, a "why bother" attitude as expressed in the following: "people are still throwing trash around and not caring at all and knowing what's going around in different places. Everyone doesn't care I don't not saying Im [sic] a follower but I don't care because why keep cleaning when people going to trash it up again." 


\section{Environmental identity}

In contrast to a lack of care of the environment, $15 \%$ of students' responses specifically referenced their feelings of care and concern for and connection to the natural world (coding category 7), which others have called an environmental identity [26, 27]. For example, one student wrote, "The work we did in our school's garden made me connect with nature" indicating that students felt connected to nature when they experienced it.

In light of the content of these PBSE projects, it is not surprising that many students referenced the fact that learning about the environment was an important step in caring for it. As one said, "in order to understand your environment fully you need to work outside and know how nature works. By understanding nature we can solve problems and search for more sustainable ways of living." Another thought their work might influence how others feel about the environment, and lead them to change their behaviors: "it helped people learn about what we studied and it showed them how we could connect with the ecosystem... I believe that because of my work people will learn to respect the environment more and not to abuse what they have."

Students alluded to the potential of these projects for instilling non-human members of the environmental commons with an identity and enabling students to form relationships with one, stating we "have to empathize with other. There is an empathetic barrier when the 'other' speaks in quacks or barks." Building relationships with and knowing that their actions can have negative consequences for other species, students become less likely to ignore the impacts of their actions. Many students wrote about the new relationships they formed: "I enjoyed learning and meeting the nature that is right here in our neighborhood" and the appreciation they gained for the role nature plays: "we have a lot of plants that play a big part in the communities... I learned about how important trees are." Finally, recognizing human reliance on nature helped some students develop an environmental sensitivity: "The work we did in our school's garden made me connect with nature and showed how I can help nature while benefitting from it myself."

\section{Interdependence}

A reliance on healthy natural systems for human wellbeing is one aspect of references to ecological interdependence and limits of natural systems, that were coded for in $20 \%$ of students' reflective essays (coding category 8). For some students, interdependence was recognized primarily as human dependence on nature, through the lens of its impact on human survival: "I think what we did in permaculture was important because we need plants to 'survive'." Others noted true interdependence between species, be it humans and another species, “... if I clean the water that's in lakes, I can save the species that live in the water such as fish, tadpols [sic] frogs, snails etc...because those things kill insects \& that helps human beings out" or between two non-human species, "I learned that frogs and mosquitos population grow/decrease are hand in hand."

In their comments highlighting interdependence, some students noted the connected consequences of humans polluting natural systems, with one referencing the positive ripple effect that their own project had initiated due to these connections: "cleaning water literally saved little fishes and frogs and without any frogs the environment wouldn't be good."

For some the delicate ecological balance and interrelationships in nature was a specific learning from their project: "We learned that one species control is by another species and if one species dies it is that other species grow rapidly. If a spcie [sic] is extinct it is a chain reaction and either a species blooms or becomes extinct." Another working on invasive species control saw this interdependence as why their work was important: "I believe the work we did removing the garlic mustard was important because garlic mustard is a type of invasive species. It was taking over a wood in our community, leaving other species with less of everything they need to survive.".

An understanding of ecological interdependence is part of the foundation for a commitment to the commons, as is an understanding of the limits of natural systems and resources. Some students resolved to "stop using so much energy" and the following elaborated on this theme, "We learned that you can't eat everything up on the earth and not put it back so therefore we plant fruits and vegatables [sic]." Referencing the dire consequences and uncertain future due to environmental degradation was also coded in this category, as an understanding of the limits of nature, such as the student who wrote, "we need to keep it clean and if we don't something terrible can happen to the earth.... I told them what could be the future earth and how would it be if the earth was not taking care of properly."

\section{Generativity}

In order to tap students' aspirations, visions, and hopes, we coded for references to generativity (coding category 9), i.e., contributions they could make or pass on that would leave a positive legacy, referenced in $25 \%$ of responses. Some students referred to a collective responsibility to future generations: "I've learned from this school learning knew [sic] things about our environment how to keep it up for future generations." As students in these projects partnered with organizations and individuals in their community, this intergenerational context meant that some students became aware of their role in 
educating elders such as the student who learned "...that kids can motivate adults" as well as the one who wrote "Kids in the community could spread information especially to their parents and encourage them to start their own garden."

The idea of leaving a positive legacy was also expressed as leadership or the idea that their behavior could act as a model for others. For some, this meant that others might emulate their behavior, as the student who expressed "...you pick up some trash in your community or plant a tree whatever you do somebody could possibly see and follow." Other students saw their efforts as inspiring others, such as the student who wrote "I think the work we did was very important because it helps to inspire other people around our community and younger generations."

\section{Efficacy and empowerment}

The sense of efficacy in their capacities to effect change also indicated in the above quote, was coded in $51 \%$ of student responses (coding category 10). Likely due to the way the question was framed, many related how kids can solve environmental problems, with some holding that youths' capacities were equal to those of adults: "I learned that kids can do anything that adults can to help for the community..." and "I learned that kids can fix large problems just like adults...The community has change because now people learn [sic] that adults aren't the only ones who can solve environmental problems." As the second quote alludes, some students suggested that a belief in youths' capacities to effect positive change challenged stereotypes about young people as one student expressed, “Most people don't think students can accomplish certain things like this but if you try and work hard enough it's possible regardless of age" and that their efforts could change that stereotype: "It proves that kids can help the environmental [sic] and we're not just little, useless objects."

Reflected in student responses was a sense of themselves as agents of change, and a belief in their capacities to take action on behalf of the larger community, as seen in the student who stated, "it was basically giving back to the community and making it better." In addition to students feeling empowered by the impact they had, many talked about the act of doing something positive itself as inspiring, as one student wrote, "I feel like I did something great and the fact that I accomplished it makes me feel amazing." Another commented:

I learned helping the school made the community look better and made kids want to be more involved and help the school to. Just being able to be a part of such a positive change is a great experience. Also cleaning up around the neighborhood. I learned kids can solve environmental problems, that they can come together and listen to ideas and think of ways to make change and make everyone feel involved.

\section{Civic skills}

Finally, $12 \%$ of the responses specifically referenced the civic or democratic skills and dynamics (coding category 11) they learned that made their work effective. As their projects were all framed as collective efforts, it is not surprising that many referenced skills in team work like the student who "learned we can work together" or the student who learned they "have to work with people who are different." While this learning is applicable in many contexts, it is imperative in caring for the commons, which necessitates collaboration with others who bring different experiences and perspectives. Indeed, students referenced the need for these skills, with one noting the importance of the work: "because you need interact [sic] with different people sometimes." Navigating how to work with those who have different opinions than ours is crucial as we negotiate how to live in community, interdependently with other living beings in our local place.

Skills around communication seemed to be a particularly important part of students' learning with one stating they learned "how to commitate [sic] with others even when there is a problem" and another "I learned how to communicate with others in a more educational way."

Other civic skills noted in their reflective essays included research, dissemination, advocacy and public presentations. As one student noted, "Simply passing out our flyers and getting input from our community helped move our project forward." Some connected their work and advocacy to electoral politics, including one who wanted to hold leaders accountable: "We must support leaders around the world who do not speak for the big polluters or the big keperations [sic]." Or the student who felt their scientific research could inform public policy: "We can write a letter to the press or mayor with our strong thesis evidence and research to ask for the money for the tools we need.... Protest to stop polluting and ask the city to make it a fine if caught, and fence it off."

\section{Discussion and conclusion}

The PBSE efforts of the SEMIS coalition of schools documented in this paper present a compelling model for preparing younger generations for the environmental challenges of the coming decades. Based on these students' reflective essays, it is clear that most are gaining insights that underpin an awareness of and capacities to sustain the environmental commons. With respect to environmental commons theory, pedagogical practices in these projects mirror Ostrom's findings on successful community management of CPR's $[11,12]$. The first 
element of Ostrom's findings, proximity, is mirrored in in these projects by drawing students' attention to the natural environment as it is affected by humans in the local place where they live and attend school. Ostrom's second element, identification with the group and its goal, is emphasized via the collective structure for learning and action in teams of students, teachers, and adult community partners. Finally, diversity in the experiences and perspectives of team members is considered an asset and dynamics within groups emphasize mutual respect and communication, a third element in Ostrom's findings.

With respect to the theme of this journal issue, several things are noteworthy. First, 32\% of responses pointed to youths' awareness of the negative impacts that humans can have on the natural environment, an awareness that was typically coupled with a resolve to re-examine and change some of their own harmful habits. This finding is consistent with environmental education research that shows students are more likely to report proenvironmental behaviors after inquiry-based local environmental issue investigations, than students in conventional classrooms [30, 31], with the most successful programs going beyond learning alone to include taking action [32].

Second, the fact that $76 \%$ of the responses referenced the positive impact humans in general and the youth themselves were having on improving the natural environment, and $25 \%$ generative concern, engenders a sense of confidence that many will change their habits. Students are more likely to report pro-environmental behaviors when they have learned how others address environmental issues [30, 31]. Likewise, environmental action is correlated with generativity in adolescents as they are more likely to engage in pro-environmental behavior if they are cognizant of the impact of their actions on future generations [33]. While it is generally accepted in environmental education theory that awareness does not necessarily lead to care and action, it is through the immersive experiences of PBSE that the students in this study are developing caring, ethical relationships with the planet and each other.

Third, the sense of pride and efficacy voiced in many reflective essays pointed to the affective rewards associated with their environmental work, increasing the likelihood that they will be proactive in the future. Results in this study support the notion that collective action is critical in developing these feelings, showcased by the fact that in projects that contained less direct action, students' reflective essays revealed less sense of pride in their community contribution, and less of a sense of efficacy. Knowledge combined with capacity for action then, is key for student efficacy and empowerment [34], especially when done with others [35]. Positive attitudes toward protecting the environment are more likely to impact high-school students' behavior if they feel capable of doing something about the problem [36].

Fourth, the fact that the projects were structured as group or team efforts added another dimension to youths' understanding, i.e., that preserving the environmental commons is everyone's responsibility and that a better outcome is achieved when everyone feels like a stakeholder. Here we emphasize the importance of the team-work and collective action framework of projects in the sense of efficacy the youth expressed. As others have emphasized [37], environmental challenges, especially of the magnitude of the climate crisis, overwhelm individuals unless people are cognizant that many others, like them, are addressing the challenge. Indeed, through their projects many youth seemed to be developing their own identities as stakeholders in the environmental commons.

Fifth, as adolescence is a time when individuals are exploring and consolidating their identities [4], the fact that so many felt that their projects had benefitted the community (57\% mentioning humans and $42 \%$ mentioning other living things as the beneficiaries) points to this PBSE model's potential for redressing the breakdown of community that Vandana Shiva [1] contends underlies the erosion of ownership and responsibility for the commons. As others have argued, [34, 38], to prepare younger generations to grapple with the climate crisis, arguably the biggest civic challenge they will face, a new ecological citizenship is called for - one that combines information with deliberation, collective agency, and a transcendence of the status quo such that "what is" need not limit the imagination of "what could be" [39].

\section{Acknowledgements}

The authors would like to thank the Southeast Michigan Stewardship Coalition (SEMIS), the GLSI, and all of the students, teachers, and community partners who participated.

\section{Authors' contributions}

EG took the lead on data collection and writing of the manuscript and collaborated with CF on the conceptualization of the manuscript. CF was the $\mathrm{PI}$ on the project and collaborated with EG on conceptualization of the manuscript, while EG, AP, and MS coded and analyzed the data and AP and MS provided feedback on the manuscript. The author (s) read and approved the final manuscript.

\section{Funding}

This work was supported by the Spencer Foundation and the Dorothy A. O'Brien Fund in Human Ecology.

\section{Availability of data and materials}

The datasets generated and/or analyzed during the current study are not publicly available due to the fact that they contain information that could compromise participant privacy/consent but are available from the corresponding author on reasonable request.

Ethics approval and consent to participate

This study was completed as an evaluation in collaboration with the SEMIS Coalition, who has permission to conduct programming and evaluation in the schools. The study was reviewed by the University of Wisconsin 
Education and Social/Behavioral Science Institutional Review Board and the IRB determined that the project is evaluation and does not constitute research as defined in 45 CFR 46.102(d). While parental consent was not required, we have followed ethical considerations in informing participants of the study, obtaining verbal assent, and maintaining the confidentiality of participants.

\section{Consent for publication}

Not applicable.

\section{Competing interests}

The authors declare that they have no competing interests.

\section{Author details}

${ }^{1}$ School of Human Ecology, University of Wisconsin-Madison, 1300 Linden Dr, Madison, WI 53706, USA. ${ }^{2}$ Department of Civil Society and Community Studies, School of Human Ecology, University of Wisconsin-Madison, 1300 Linden Dr, Madison, WI 53706, USA.

Received: 28 June 2019 Accepted: 7 May 2020

Published online: 27 May 2020

\section{References}

1. Shiva V. Earth democracy: justice, sustainability and peace. Cambridge, MA: South End Press; 2005.

2. Giddens A. The politics of climate change. Cambridge: Polity Press; 2009.

3. White R. Climate change, uncertain futures, and the sociology of youth. Youth Studies Australia, vol. 30; 2011. p. 13-9.

4. Erikson H. Identity: youth and crisis. New York: W.W. Norton Company; 1968

5. United Nations Department of Economic and Social Affairs, Population Division (2018). World Urbanization Prospects: The 2018 Revision. Retrieved from https://www.un.org/development/desa/publications/2018-revision-ofworld-urbanization-prospects.html.

6. Gallay EE, Flanagan C. Civic environmentalism: social responsibility for public resources. In: Brown PM, Corrigan M, Higgins-D'Alessandro A, editors. Handbook on Prosocial Education. Lanham, MD: Rowan and Littlefield; 2012. p. 171-8.

7. Flanagan C, Gallay E. Adolescents' theories of the 'commons'. In: Benson J, editor. Advances in Child Development and Behavior, vol. 46. Oxfordshire, UK: Elsevier; 2014. p. 33-55. https://doi.org/10.1016/B978-0-12-800285-8. 00002-9.

8. Flanagan C, Byington R, Gallay E, Sambo A. Social justice and the environmental commons. In: Horn S, Ruck M, Liben L, editors. Advances in Child Development and Behavior, equity and justice in developmental sciences: implications for young people, families, and communities. Oxfordshire: Elsevier; 2016. p. 203-30.

9. Gallay E, Marckini-Polk L, Schroeder B, Flanagan C. Place-based stewardship education: nurturing aspiration to protect the rural commons. Peabody J Educ. 2016b;91:155-75. https://doi.org/10.1080/0161956x.2016.1151736.

10. Hardin G. The tragedy of the commons. Science. 1968;162(3859):1243-8. https://doi.org/10.1126/science.162.3859.1243.

11. Ostrom E. Beyond markets and states: polycentric governance of complex economic systems. Am Econ Rev. 2010;100(3):641-72. https://doi.org/10. 1257/aer.100.3.641.

12. Cardenas J, Ostrom E. How norms help reduce the tragedy of the commons: a multi-layer framework for analyzing field experiments. In J.N. Drobak (Ed.), Norms and the Law (pp. 105-136). New York, NY: Cambridge University Press; 2006. https://doi.org/10.1017/CBO9780511617720.007.

13. Grist. (2006). Introducing a seven-week series on the intersection of economic and ecological survival. Grist. Retrieved from http://grist.org/ article/pate/.

14. Samson J, Berteaux D, McGill B, Humphries M. Geographic disparities and moral hazards in the predicted impacts of climate change on human populations. Glob Ecol Biogeogr. 2011;20(4):532-44. https://doi.org/10.1111/ j.1466-8238.2010.00632.x.

15. Purifoy, D. (2018). On the stubborn whiteness of environmentalism. Inside Higher Ed, Web. https://www.insidehighered.com/advice/2018/06/22/how environmentalism-academe-today-excludes-people-color-opinion.

16. Taylor DE. Toxic communities: environmental racism, industrial pollution, and residential mobility. New York, NY: New York University Press; 2014.
17. Finney C. Black faces, white spaces: reimagining the relationships of AfricanAmericans to the great outdoors. Chapel Hill, NC: University of North Carolina Press; 2014

18. Krasny ME, Tidball KG. Applying a resilience systems framework to urban environmental education. Environ Educ Res. 2009;15(4):465-82. https://doi.org/10.1080/13504620903003290.

19. Russ A, Krasny ME, editors. Urban environmental education review. Ithaca, NY: Cornell University Press; 2017.

20. Gallay E, Lupinacci J, Sarmiento C, Flanagan C, Lowenstein E. Environmental stewardship and youth activism for the environmental commons. In: Conner J, Rosen S, editors. Contemporary youth activism: advancing social justice in the United States. Santa Barbara, CA: ABC-CLIO Praeger Publishing; 2016a. p. 113-32.

21. Quiroz-Martinez J, Wu DP, Zimmerman K. ReGeneration: young people shaping environmental justice. Oakland, CA: Movement Strategy Center; 2005.

22. Gruenewald DA, Smith G, editors. Place-based education in the global age: local diversity. New York: Lawrence Erlbaum Associates; 2008. ISBN 13-978-08058-5864-8.

23. Theobald P. Teaching the commons: place, pride, and the renewal of community. New York: Westview Press; 1997.

24. Theobald P. A case for inserting community into public school curriculum. Am J Educ. 2006;112(3):315-34.

25. Smith GA, Sobel D. Place- and community-based education in schools. New York: Routledge; 2010.

26. Clayton S. Environmental identity: a conceptual and an operational definition. In: Clayton S, Opotow S, editors. Identity and the natural environment. Cambridge, MA: MIT Press; 2003. p. 45-65. https://doi.org/10. 7551/mitpress/3644.003.0005

27. Jia F, Alisat S, Soucie K, Pratt M. Generative concern and environmentalism: a mixed methods longitudinal study of emerging and young adults. Emerging Adulthood. 2015;3:306-19. https://doi.org/10.1177/ 2167696815578338

28. Martusewicz RA, Edmundson J, Lupinacci J. EcoJustice education: toward diverse, democratic and sustainable communities. 2nd ed. New York, NY: Routledge; 2015.

29. Wilson EO. Biophilia. Cambridge, MA: Harvard University Press; 1984.

30. Chawla L, Derr V. The developments of conservation behaviors in childhood and youth. In: Clayton S, editor. The Oxford handbook of environmental and conservation psychology. Oxford, England: Oxford University Press; 2012. p. 537-55.

31. Hungerford H, Litherland R, Peytone R, Ramsey J, Volk T. Investigating and valuating environmental issues and action skill development program. Champaign, IL: Stipes; 2003.

32. Sobel D. Childhood and nature: Design principles for educators. Portland: Stenhouse; 2008.

33. Pratt MW, Norris JE, Alisat S, Bisson E. Earth mothers (and fathers): examining generativity and environmental concerns in adolescents and their parents. J Moral Educ. 2013;42(1):12-27. https://doi.org/10.1080/ 03057240.2012 .714751

34. Chawla L. Nature-based learning for student achievement and ecological citizenship. In: Bohan CH, editor. Curriculum and Teaching Dialogue, 20, 1 \& 2; 2018. (pp. xxV-Xxxix).

35. Doherty T, Clayton S. The psychological impacts of global climate change. Am Psychol. 2011;66(4):265-76.

36. Meinhold J, Malkus A. Adolescent environmental behaviors. Environ Behav. 2005;17:511-32.

37. Roser-Renouf C, Maibach EW, Leiserowitz A, Zhao X. The genesis of climate change activism: from key beliefs to political action. Climate Change. 2014; https://doi.org/10.1007/s10584-014-1173-5.

38. Kelly J, Abel T. Fostering ecological citizenship: the case of environmental service-learning in Costa Rica. Huxley College on the Peninsulas Publications, vol. 2; 2012. https://cedar.wwu.edu/hcop_facpubs/2.

39. Hayward B. Children, citizenship, and environment: nurturing a democratic imagination in a changing world. London, U.K.: Routledge; 2012.

\section{Publisher's Note}

Springer Nature remains neutral with regard to jurisdictional claims in published maps and institutional affiliations. 